\title{
Morphological and Physiological Responses of Indigofera tinctoria L. to Light Intensity
}

\author{
Desy Setyaningrum ${ }^{1}$, Maria Theresia Sri Budiastuti ${ }^{2, *}$, Bambang Pujiasmanto $^{2}$, \\ Djoko Purnomo ${ }^{2}$, and Supriyono Supriyono ${ }^{2}$ \\ ${ }^{1}$ Master Degree of Agronomy, Graduated School, Universitas Sebelas Maret, \\ Surakarta 17126, Indonesia \\ ${ }^{2}$ Department of Agrotechnology, Faculty of Agriculture, Universitas Sebelas Maret, \\ Surakarta 17126, Indonesia
}

\begin{abstract}
Synthetic dyes can cause health and environmental impacts. Thus, there are opportunities to develop natural dyes, one of which is produced by Indigofera tinctoria plants. This plant is from Fabaceae that has the potential to produce a natural blue color. Natural dyes are extracted from the leaves of plants that contain indigo compounds. Indigo growth and precursors are very dependent on environmental conditions, one of which is light intensity. This study aimed to study the morphological and physiological plant responses in I. tinctoria to several levels of light intensity. The research was conducted in Puron Village, Sukoharjo, Indonesia with a complete randomized block design (RCBD) one factor, namely the level of light intensity $(100 \%, 50 \%$, and $25 \%)$ with nine replications. Light intensity affected the morphology and physiology of I. tinctoria. Plants responded to low light intensity by increasing the leaf area index, specific leaf area and plant height. Leaf area, specific leaf area and plant height were highest at $25 \%$ intensity. However, the number of leaves and nodes got greater at full light intensity. Higher light intensity increased the chlorophyll content $\mathrm{a}, \mathrm{b}$ and total, thus, higher biomass yield which was $18.86 \mathrm{~g}$ at the age of $8 \mathrm{wk}$.
\end{abstract}

Keywords: Chlorophyll, leaf area, number of nodes, plant height, specific leaf area.

\section{Introduction}

Textile industries use synthetic dye for dying medium. Synthetic medium has some benefits in terms of characteristics; bright color, easily dissolves in water, cheaper to produce, and easier to apply on fabric [1]. Thus, the waste from these industries contains various types of synthetic dyes. The waste is considered a pollutant [2]. The waste treatment process is not yet efficient. It can cause serious environmental problems in connection with the reuse of wastewater for irrigation. Applying proper treatment process is very important in order to minimize pollution, one of which is by developing the production of the Indigofera tinctorial L. plant to be used as natural dyes.

\footnotetext{
* Corresponding author: mariatheresia@staff.uns.ac.id
} 
I. tinctoria is from the Fabaceae family, which is efficacious as a natural dye industry. The plant is used as a natural dye agent in the textile industry because it contains indigo pigments that produce indigo colors [3]. I. tinctoria natural dyes were the main product of India and West Africa before the discovery of synthetic indigo. Natural dye compounds are extracted from plant leaves. These plant cells contain indican secondary metabolites (indoxyl- $\beta$-D-glucoside) and/or B (1H-Indol-3-yl $\beta$-D-ribo-3-hexosulopyranoside) precursors. Indican is synthesized in chloroplasts and stored in vacuoles.

Indigo growth and precursors are highly dependent on environmental conditions, one of which is light intensity. In Europe, this plant can adapt well but is not resistant to drought, and indigo content is positively influenced by the intensity of sunlight [4]. Light is the main environmental component that affects the survival rate, morphological characteristics, photosynthetic characteristics, and primary and secondary metabolism of plants [5]. Light is a vital resource for plants, and light deficiency can directly change the development of the photosynthetic apparatus of plant photosynthetic capacity [6]. Most pigments that are specifically bound to thylakoids and the photosynthetic system are strongly influenced by the availability of light. This research aimed to study the morphological and physiological responses of I. tinctoria to several levels of light intensity.

\section{Materials and methods}

The research was conducted from April to August 2019 in Puron Village, Bulu, Sukoharjo, Central Java, Indonesia. The research location was at $77.745 \mathrm{~S}$ and $110.83 \mathrm{E}$ with an altitude of 120 m.a.s.1. Microclimatic conditions with an average precipitation of $2289 \mathrm{~mm} \mathrm{yr}^{-1}$ and the number of rainy days $105 \mathrm{~d}$. Daily average temperature of $25{ }^{\circ} \mathrm{C}$ to $27{ }^{\circ} \mathrm{C}$, humidity around $80 \%$. The study used a complete randomized block design (RCBD) with one factor, the light intensity with three levels; $100 \%, 50 \%$, and $25 \%$. All treatment was replicated with nine replications, so there were 27 experiment units. The planting material used was I. tinctoria seeds, which are green in color. The tool used as an application of light intensity was a shading net with various density levels.

Chlorophyll analysis was carried out at Laboratorium Fisiologi Tumbuhan Universitas Sebelas Maret using the Armon [7] method with a slight modification. Chlorophyll a and b uptake was measured using a UV-Visible Double-ray Spectrophotometer (Eliso S1-156, India) at 663 and $645 \mathrm{~nm}$ by using acetone $90 \%$ as the blank. Plant physiology variables observed were chlorophyll a, b, and total, the biomass of plants aging $6 \mathrm{wk}, 8 \mathrm{wk}$, and $10 \mathrm{wk}$. Morphological variables recorded were plant height, number of leaves, number of branches, leaf area, specific leaf area (LW/LA: LW = leaf weight, and LA=leaf area). The data were analyzed using analysis of variance with $\alpha 5 \%$ (95\% confidence level) followed by a $5 \%$ Duncan's Multiple Range Test (DMRT) if between the experimental units were significantly different.

Environmental variables observed were light intensity at 7 a.m., 12 p.m., and 5 p.m. $($ GMT+7) using lux meter (Mextech, China), temperature, and humidity using Thermo hygrometer (Shanghai, China). Observations of the environment were carried out 12 times, starting at the age of $7 \mathrm{~d}$ plants until harvest time. Observation of light intensity was carried out on the canopy of I. tinctoria ie, under the third leaf from above. 
Table 1. Average environmental variables in the research location

\begin{tabular}{|c|c|c|c|c|}
\hline \multirow{2}{*}{$\begin{array}{c}\text { Light } \\
\text { intensity }\end{array}$} & Variable & \multicolumn{3}{|c|}{ Time of observation (GMT+7) } \\
\cline { 3 - 5 } & & $\mathbf{7}$ a.m. & $\mathbf{1 2}$ p.m. & $\mathbf{5}$ p.m. \\
\hline \multirow{3}{*}{$100 \%$} & Light intensity (lux) & 48600 & 63200 & 16010 \\
\cline { 2 - 5 } & Temperature $\left({ }^{\circ} \mathrm{C}\right)$ & 27.8 & 36.7 & 29.6 \\
\cline { 2 - 5 } & Relative humidity (\%) & 64 & 46 & 54 \\
\hline $50 \%$ & Light intensity (lux) & 24600 & 32400 & 8430 \\
\hline & Temperature $\left({ }^{\circ} \mathrm{C}\right)$ & 27 & 34.2 & 28.9 \\
\hline & Relative humidity (\%) & 63 & 41 & 56 \\
\hline & Light intensity (lux) & 13600 & 5300 & 4025 \\
\hline & Temperature $\left({ }^{\circ} \mathrm{C}\right)$ & 26.4 & 32 & 28.3 \\
\hline & Relative humidity $(\%)$ & 66 & 50 & 57 \\
\hline
\end{tabular}

\section{Results and discussions}

\subsection{Morphological responses of $I$. tinctoria to light intensity}

Plant morphology has manipulability and adaptation mechanisms in changing environmental conditions [8]. Light intensity significantly affected the growth of I. tinctoria plants at 2 wk to 12 wk old (Figure 1). Different light conditions had different effects on plant height. Plants grew higher with lower light intensity levels. This condition indicated that the stem of the I. tinctoria plant was etiolated. This is in accordance with the research of [9] that shading caused an increase in the height of soybean plant stems. Low light caused the internodes to grow longer [10]. Adaptation of plants to low light intensity would affect the morphology, anatomy, and physiology of plants, including an increase in leaf area and plant height as an effort to reduce the use of metabolites, and reduce the light transmitted and reflected [11].

I. tinctoria plant height at full light intensity was only $73.44 \mathrm{~cm}$, while at $50 \%$ intensity, the plant height increased by $37.34 \%$, which reached $117.22 \mathrm{~cm}$ and increased $40.72 \%$ at $25 \%$ intensity. Plants responded to stem elongation and inhibited the growth of stem diameter to absorb a high amount of light [12]. This was due to the low light, which activated auxin and further caused symptoms of etiolation [13]. Shading application led to carbon allocation towards stems elongation at the expense of roots and leaves development, thereby affecting the yield [14].

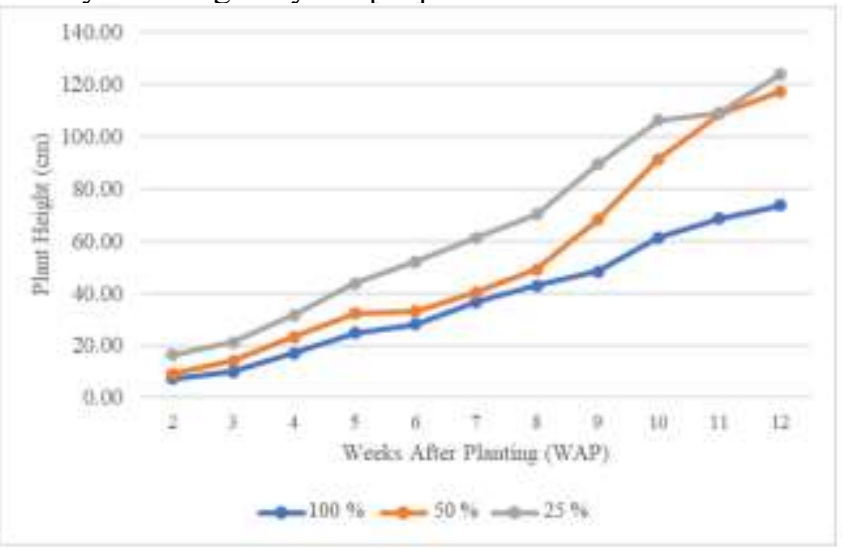

Fig. 1. Effect of light intensity on plant height 
Leaves are considered as the head part of the plant. Leaf functions to collect light energy from the sun and play a role in photosynthesis to convert light energy into biochemical energy [15]. The number of leaves was considered a major factor that determined the quality of growth and the ability of plant photosynthesis. The results showed that the number of I. tinctoria leaves reached 368 strands in full light intensity at 12 WAT (Table 1). The number of leaves at each intensity showed significantly different results. The number of leaves at $50 \%$ light intensity decreased by $39 \%$ reached 225 strands and at $25 \%$ light decreased by $51.79 \%$. The growth of nodes also decreased at a low light intensity. The results showed that the number of nodes at each intensity was significantly different. The number of nodes in full light reached 28 nodes. In $50 \%$ intensity number of media is reduced by $41.69 \%$ reached only 16 nodes. Plants responded to low light by extending internodes and leaf stalks, resulting in reduced nodes. Thus, the number of leaves was also reduced. Light intensity-modulated the content of the thylakoids as the PSII/PSI ratio, the number of reaction centers. Plants in low light exhibited lower levels of photosystem II (PSII), number of reaction centers, as well as the decreased capacity for oxygen evolution, electron transport, and limitations in electron transport between PSII and PSI [16]. An important effect of low light was the reduction in clean photosynthesis [17]. Decreased photosynthesis occurred from two main mechanisms: i) a decrease in diffusion of $\mathrm{CO}_{2}$ into leaves, due to decreased inter-cell $\mathrm{CO}_{2}$ and stomatal conductance, and ii) potential inhibitory metabolism for photosynthesis by inhibiting leaf growth and enlargement by controlling cell proliferation [18].

Leaf area shows the ability of plants to carry out photosynthesis because it is associated with the use of light and the use of growing facilities [19]. The results of this study indicated that light intensity significantly influenced the area of I. tinctoria leaves. Leaf area reached 40.22 at $25 \%$ light; at $50 \%$ light, the leaf area was reduced by $19 \%$ and reduced by $61 \%$ at $100 \%$ light. It showed that plants responded to low light by increasing leaf area. Reduced light supply encourages an increase in leaf area [20], which is an attempt by plants to increase the area of light absorption and light capture efficiency [21]. The optimum leaf area shows that sunlight is received evenly by the leaf [22].

The specific leaf area (SLA) at $50 \%$ light was $63.98 \mathrm{~cm}^{2} \mathrm{~g}^{-1}, 19 \%$ higher than full light, and $2.1 \%$ higher than $50 \%$ light. Specific leaf area at light $25 \%$ and $50 \%$ did not show significantly different. Such a situation also appeared in soybean crop yielded in the research of [6] that SLAs were increased in low light. An increase in specific leaf area due to phototropism [23, 8]. However, an increase in SLA was not able to compensate for the decrease in leaf area caused by reduced light interception. Tolerant of intolerant species to low light would optimize the capture and utilization of the light by increasing SLAs [14], because SLA was an important parameter that reflected plant growth and carbon assimilation and was strongly influenced by changes in light conditions [24, 25].

Table 2. Light intensity on the growth of I. tinctoria

\begin{tabular}{|c|c|c|c|c|}
\hline $\begin{array}{c}\text { Light } \\
\text { intensity }(\%)\end{array}$ & $\begin{array}{c}\text { Number of } \\
\text { leaves (strand) }\end{array}$ & Leaf area & $\begin{array}{c}\text { Specific leaf } \\
\text { area }\left(\mathrm{cm}^{2} \mathbf{g}^{-1}\right)\end{array}$ & $\begin{array}{c}\text { Number of } \\
\text { nodes }\end{array}$ \\
\hline 100 & $368.56 \mathrm{~b}$ & $15.65 \mathrm{a}$ & $46.10 \mathrm{a}$ & $28.78 \mathrm{~b}$ \\
\hline 50 & $225.00 \mathrm{a}$ & $32.24 b$ & $65.36 \mathrm{~b}$ & $16.78 \mathrm{ab}$ \\
\hline 25 & $177.67 \mathrm{a}$ & $40.22 c$ & $63.98 \mathrm{~b}$ & $13.11 \mathrm{a}$ \\
\hline
\end{tabular}




\subsection{Physiology plant response in I. tinctoria to light intensity}

The light intensity had a significant effect on chlorophyll (Table 4). The amount of chlorophyll at a full light intensity and $50 \%$ were not significantly different, at $25 \%$ intensity showed significantly different and decreased by $6 \%$. Light intensity on chlorophyll $\mathrm{b}$ and total chlorophyll had no significant difference. Chlorophyll $\mathrm{b}$ and total decreased at a low light intensity. The decrease in chlorophyll b in light of $25 \%$ was $2.4 \%$, the decrease in total chlorophyll was $4.5 \%$. These results indicated that low light decreased chlorophyll $\mathrm{a}, \mathrm{b}$ and total in I. tinctoria. These results are in accordance with the results of the study of [26] that decreasing the shading from T75 to T0 increases the content of $\mathrm{Chl} \mathrm{a,} \mathrm{Chl} \mathrm{b,} \mathrm{and} \mathrm{Chl} \mathrm{a}+\mathrm{b}$ in soybeans. Chlorophyll content also showed a decrease in water spinach planted under shading net [27]. Under changing light conditions, studies of $\mathrm{Chl} \mathrm{a,} \mathrm{Chl} \mathrm{b,} \mathrm{and} \mathrm{Chl} \mathrm{a}+\mathrm{b}$ help as an index for sunlight absorption [28]. The amount of Chl was significantly affected by changes in light availability and decreased with the reduction in light [29]. Chlorophyll content acts as an important factor in determining plant photosynthesis [30]. Increased $\mathrm{Chl} b$ increases light interception under shading stress [31]. The amount of chlorophyll in shade-resistant plants increases under shading [32]. His research shows that the shade increases the content of chlorophyll $a, b$, and total and photosynthetic activity. This may indicate that the $I$. tinctoria plant is intolerant of low light.

Table 3. Light Intensity toward chlorophyll content of I. tinctoria

\begin{tabular}{|c|c|c|c|}
\hline Light intensity & \multicolumn{3}{|c|}{ Chlorophyll } \\
\cline { 2 - 4 }$(\boldsymbol{\%})$ & $\mathbf{A}$ & $\mathbf{b}$ & total $(\mathbf{a}+\mathbf{b})$ \\
\hline 100 & $0.519 \mathrm{~b}$ & $0.867 \mathrm{a}$ & $1.386 \mathrm{a}$ \\
\hline 50 & $0.512 \mathrm{ab}$ & $0.846 \mathrm{a}$ & $1.358 \mathrm{a}$ \\
\hline 25 & $0.487 \mathrm{a}$ & $0.840 \mathrm{a}$ & $1.327 \mathrm{a}$ \\
\hline
\end{tabular}

I. tinctoria biomass increased as plant aged. The light intensity did not significantly affect the biomass of I. tinctoria at 6 WAP. Low light showed the greatest biomass at 6 WAP. Plant biomass at 6 WAP at each light intensity level was not significantly different. According to Yao et al. [32], leaf area is an important factor affecting plant light and biomass interception. The yield of plant biomass at $6 \mathrm{WAP}$ had a linear relationship with the leaf area that the highest biomass resulted in light $25 \%$. A significant linear relationship between leaf area and biomass per plant in shady conditions [33]. This is because the reduction in leaf area directly impacts the reduction in photosynthate production. Some studies have shown that increasing the leaf area increased the rate of net photosynthesis [34]. However, this was incompatible with the I. tinctoria biomass at $8 \mathrm{WAP}$ and $10 \mathrm{WAP}$ that at full light, the leaf area was low, and biomass production was high. [19] stated that the decrease in SLA would be offset by an increase in crop dry weight. Plants with low SLA value would have narrower and thicker leaves but have a great dry plant production. This study showed that light intensity affected biomass at 8 and $10 \mathrm{WAP}$, full light could produce the greatest amount of biomass that was 18.86 at $10 \mathrm{WAP}, 27 \%$ greater than light $25 \%$ and $18 \%$ greater than biomass at $50 \%$ light. These results indicated that the biomass of I. tinctoria increased in full light. This is because biomass was a product of photosynthesis that depended on the availability of light to produce carbohydrates. Plants that received low light modified the number of nodes to be very low and stimulated the plant stem internodes, causing reduced leaves to grow and reduced the number of nodes resulting in reduced biomass production. Adapting the mechanism of plants in various light environments was by changing the characteristics of photosynthesis. The rate of net photosynthesis decreases, resulting in a reduction in plant biomass in low light [35]. This is in accordance with the results of [36] research that biomass production has a linear 
relationship with the chlorophyll content of plants, ie the production of biomass and chlorophyll content decreases at low light. Low light intensity caused an increase in plant height, leaf area, and specific leaf area (SLA). These morphological changes allowed relatively more light interception and increased the efficiency of light use in I. tinctoria due to the shading effect.

Table 3. Light intensity on biomass production

\begin{tabular}{|c|c|c|c|}
\hline $\begin{array}{c}\text { Light intensity } \\
(\%)\end{array}$ & 6 WAP & 8 WAP & 10 WAP \\
\cline { 2 - 4 } & $10.21 \mathrm{a}$ & $16.04 \mathrm{~b}$ & $18.86 \mathrm{~b}$ \\
\hline 100 & $11.09 \mathrm{a}$ & $14.30 \mathrm{ab}$ & $16.37 \mathrm{ab}$ \\
\hline 50 & $14.47 \mathrm{a}$ & $11.70 \mathrm{a}$ & $13.65 \mathrm{a}$ \\
\hline 25 & \multicolumn{3}{|c|}{} \\
\hline
\end{tabular}

\section{Conclusion}

Light intensity affected the morphology and physiology of I. tinctoria. Plants responded to low light intensity by increasing plant height, leaf area index, specific leaf area. Leaf area, specific leaf area, and plant height were highest at $25 \%$ intensity. An increase in leaf area had a linear relationship with biomass at 6 WAP that the highest biomass production at light $25 \%$. However, biomass production at $8 \mathrm{WAP}$ and $10 \mathrm{WAP}$ was strongly influenced by high light reaching $18.83 \mathrm{~g}$. An increase in biomass was due to the number of leaves, the higher number of nodes in full light. Light intensity affected chlorophyll, the chlorophyll content increased in high light, thus, providing materials and energy base for photosynthesis.

\section{References}

1. D. Karadag, E. Akgul, S. Tok, F. Erturk. J Chem. Eng. Data. 52,6:2436-2441(2007) Doi: $10.1021 / \mathrm{je} 7003726$

2. P. Sharma. Environ. Monit. Assess. 183:151-195(2011). DOI 10.1007/s10661-011$\underline{1914-}$

3. M.R. Hariri, T. Chikmawati, A. Hartana. J Math. Found. Sci., 49,2:105-115(2017). DOI: $10.5614 /$ j.math.fund.sci.2017.49.2.1

4. L.G. Angelini, S. Tozzi, N.N.o.D. Nasso. J. Agri. Food Chem., 52,25:75417547(2004). https://pubmed.ncbi.nlm.nih.gov/15675801/

5. U. Niinemets, T.F. Keenan, L. Hallik. New Phytol. 205,3:973-993(2015). https://pubmed.ncbi.nlm.nih.gov/25318596/

6. Y.S. Wu, F. Yang, W.Z. Gong, S. Ahmed, Y.F. Fan, X.L. Wu, et al. J. Integr. Agric. 16,6:1331-1340(2017). https://doi.org/10.1016/S2095-3119(16)61525-3

7. D.I. Arnon. Plant Physiol. 24:1-15(1949).

8. W.G. Gong, C.D. Jiang, Y.S Wu, H.H. Chen, W.Y. Liu, W.Y. Yang. Photosynthetica, 53:259-268(2015). DOI: 10.1007/s11099-015-0103-8

9. J. Bakhshy, K.G. Golezani, S.Z. Salmasi, M.M. Vahed. Tech. J.Eng. Appl. Sci. 3,1:30-43(2013).

https://www.researchgate.net/publication/235798162_Effects_of_Water_Deficit_an d_Shading_on_Morphology_and_Grain_Yield_of_Soybean_Glycine_Max_L

10. M. Lukitasari. Jurnal IKIP PGRI Madiun. 1-8(2012). https://www.academia.edu/6301530/PENGARUH_INTENSITAS_CAHAYA_MAT AHARI_TERHADAP_PERTUMBUHAN_TANAMAN_KEDELAI_GLYCINE_M $\underline{\mathrm{AX}}$ 
11. M.G. Hale, D.M. Orcutt. Allelochemical stress, in M. G. Hale and D. M. Orcutt (eds.). The Physiology of Plants under Stress. John Wiley \& Sons, New York. (1987).p.127

12. M. Kermah, A.C. Franke, S.A. Nsiah, B.D.K. Ahiabor, R.C. Abaidoo, K.E. Giller. Field Crops Res. 213:38-50(2017). https://doi.org/10.1016/j.fcr.2017.07.008 PMID: 29104356.

13. Y. Wu, W. Gong, W. Yang. Scientific reports. 7:9259(2017). DOI:10.1038/s41598-017-10026-5

14. C.M.M. Gommers, E. Visser, K. Onge, L. Voesenek, R. Pierik. Trends in Plant Science, 18,2:65-71(2013). DOI: 10.1016/j.tplants.2012.09.008

15. F. Sukriah, L. Pranggarani. Jurnal Ilmiah Fifo. 8,1:20-43(2016). [in Bahasa Indonesia].

http://digilib.mercubuana.ac.id/manager/t!@file_artikel_abstrak/Isi_Artikel_258872 $\underline{\text { 346718.pdf }}$

16. K. Kunderlikova, M. Brectic, M. Zivcak, P. Kusniarova. J. Cent. Eur. Agric. 17,4:950-956(2014). DOI: 10.5513/JCEA01/17.4.1797

17. C. Yang, B. Hu, N. Igbal, F. Yang, W.g. Liu, X.c. Wang, et al. J Plant Prod. Sci. 21,3:193-202(2018). DOI: 10.1080/1343943X.2018.1484257.

18. L.Y. Feng, M.A. Raza, Z.C. Li, Y. Chen, M.H.B. Khalid, J. Du, et al. Front Plant Sci. 9:1952(2018). https://doi.org/10.3389/fpls.2018.01952

19. S.M. Sitompul, B. Guritno. Analisis Pertumbuhan Tanaman. Malang, Fakultas Pertanian Universitas Brawijaya. (1995)

20. H. Poorter, K.J. Niklas, P.B. Reich, J. Oleksyn, P. Poot, L. Mommer. New Phytologist. 193,1:30-50(2012). https://doi.org/10.1111/j.1469-8137.2011.03952.x

21. Chairudin, Efendi, Sabaruddin. Jurnal Floratek. 10,1:26-35(2015). http://jurnal.unsyiah.ac.id/floratek/article/view/2355/2240

22. C.R. Brodersen, T.C. Vogelmann TC. Funct Plant Bio. 37:403-413(2010). http://citeseerx.ist.psu.edu/viewdoc/download?doi=10.1.1.839.5572\&rep=rep1\&typ $\mathrm{e}=\mathrm{pdf}$

23. F. Yang, D. Liao, X. Wu, R. Gao, Y. Fan, M.A. Raba, et al. Field Crops Res. 203:16-23(2017). DOI: 10.1016/j.fcr.2016.12.007

24. F. Yang, L. Feng, Q. Liu, X. Wu, Y. Fan, M.A. Raza, et al. Environ. Exp. Bot. 150:79-87(2018) Https://doi.org/10.1016/j.envexpbot.2018.03.008 .

25. F. Valladares, U. Niinemets. Annu.Rev. Ecol. Evol. Syst. 39: 237-257(2008). DOI: 10.1146/annurev.ecolsys.39.110707.173506 https://www.annualreviews.org/doi/abs/10.1146/annurev.ecolsys.39.110707.173506

26. M.H.B. Khalid, M.A. Raza, H.Q. Yu, F.A. Sun, Y.Y. Zhang, F.Z. Lu,et al. Appl. Ecol. Environ. Res. 17,2:2551-2569(2019). Doi:

http://Dx.Doi.Org/10.15666/Aeer/1702_25512569

or

https://www.google.com/url?sa=t\&rct=j\&q=\&esrc=s\&source=web\&cd=\&ved $=2 \mathrm{ah}$

UKEwjYqbbT7tfrAhXNc30KHQQ8BngQFjAAegQIARAB\&url=http $\% 3 \mathrm{~A} \% 2 \mathrm{~F} \% 2$

Faloki.hu\%2Fpdf\%2F1702_25512569.pdf\&usg=AOvVaw2ZyLccjZ7UfY1AnDOU

PowQ.

27. D. Wulandari, N. Sofiyanti, Fitmawati. Jurnal Riau Biologia. 1,2:135-139(2016). [in Bahasa Indonesia]. https://jrb.ejournal.unri.ac.id/index.php/JRB/article/view/3773

28. Y. Fan, J. Chen, Y. Cheng, M.A. Raza, X. Wu, Z. Wang Z, et al. Plos ONE 13,5: e0198159(2018). https://doi.org/10.1371/journal.pone.0198159.

29. R. Li, T. Wen, Y.T. Tang, X. Sun, C. Xia, Acta Pratac. Sin. 23:198-206(2014).

30. Y. Zhou, L. Huang, X. Wei, H. Zhou, X. Chen. Plant Growth Regul. 81:1-8(2016). DOI $10.1007 / \mathrm{s} 10725-016-0181-\mathrm{Z}$ 
31. R.W. Pearcy, J.R. Seemann. Plant Physiol. 94,2:628-633(1990).

doi: $10.1104 /$ pp.94.2.628

32. X. Yao, C. Li, S. Li, Q. Zhu, H. Zhang, H. Wang, et al. Plant Growth Regul. 83: 1-8(2017). Doi: 10.1007/s10725-017-0307-y.

33. N. Wang, Q. Huang, J. Sun, S. Yan, C. Ding, X. Mei, et al. For. Ecol. Manag. 331:40-49(2014). https://doi.org/10.1016/j.foreco.2014.06.046

34. S.P. Sulandjari, S. Wisnubroto, D. Indradewa. Jurnal Agrosains. 7:71-76(2005). [in Bahasa Indonesia]. $\underline{\text { https://scholar.google.co.id/scholar?hl=en\&as_sdt }=0,5 \& \text { cluster }=1806564267889936}$ $\underline{6887}$

35. B.Y. Su, Y.X. Song, C. Song, L. Cui, T.W. Yong, W.Y. Yang. Photosynthetica, 52: 332-340(2014). https://link.springer.com/article/10.1007/s11099-014-0036-7

36. F. Yang, Y. Fan, X. Wu, Y. Cheng, Q. Liu, L. Feng, et al. Front. Plant Sci. 9:56(2018). Doi: 10.3389/fpls.2018.00056 